\title{
SOME THOUGHTS ON THE TRAINING OF TEACHERS OF GIFTED \\ LEARNERS
}

\author{
Carol van der Westhuizen \& Jacobus G. Maree ${ }^{1}$ \\ Education Faculty, University of Pretoria, Pretoria, South Africa
}

Abstract

Ten years after the demise of the apartheid system in South Africa (SA), the ratio achieving gifted: non-achieving gifted is still woefully inadequate. The need for gifted learners to be better equipped for the challenges of a post-modern society and tertiary study needs to be highlighted, since far too many of the gifted currently do not stand even the remotest chance of achieving up to near their potential. Furthermore, the narrative of democratic change in SA during the final decade of the $20^{\text {th }}$ century has been a chronicle of the demise of a "racially and culturally segregated and differentiated education system based on the ideology of Christian National Education" (Porteus, 2003: 13).

The equality clause in the Constitution implies that all citizens will be treated equally, viz. "Equality includes the full and equal enjoyment of all rights and freedoms ... The state may not discriminate directly or indirectly against anyone on one or more grounds ..." (1996, Constitution of the Republic of South Africa, Section 9, Chapter 2). Yet, there is some concern about the possibility that gifted children might be "viewed with mistrust and dislike and deliberately ostracised" and that their human rights will not be recognised (Kokot, 1998: 2) under the new dispensation (also see Sherman, 1997: 3). Despite the publication of a number of official and media reports on challenges in education, "the plight of the gifted learner is seldom mentioned" (Kokot, 1999: 270).

In the light of the aforementioned, the purpose of this article is to examine the necessity for and the provision of suitable training for teachers who are required to provide for the needs of gifted learners in the mainstream.

\footnotetext{
${ }^{1}$ We express our gratitude to Mrs. Elsabè Olivier, Academic Information Services: University of Pretoria, who provided invaluable support during the process of retrieving information.
} 


\section{Research design}

We chose a multimethod (QUAL-quan) mode of inquiry, involving a combination of qualitative and semi-quantitative methods. We selected an explorative, interpretative approach, implying that the aim was to understand epistemologically in a trustworthy way, but nonetheless accepting that researchers' perceptions of reality not only vary, but, in fact, differ greatly.

\section{Sample Selection}

Three and four universities respectively (see next section) were randomly selected to ascertain (by examining the relevant yearbooks) the extent of courses on gifted education. In addition twelve universities were included in a brief telephonic survey (including the seven in the yearbook survey) to determine whether the curricula had changed after 2004.

\section{Data Collection, Intervention, Processing of Data and Results}

The qualitative part of the research comprises a literature study to obtain information regarding possible ways in which teachers could be trained to plan and teach the gifted.

The quantitative part of the study comprises the perusal of the 2002/2003 and 2004 yearbooks of three and four universities respectively (mentioned above) to ascertain the extent of courses on gifted education. In addition, a brief telephonic survey was conducted among twelve universities (including the seven in the yearbook survey) to determine whether the curricula had changed after 2004.

\section{Contextualising the research}

\section{Ever-increasing poverty levels in SA}


The current research should be viewed against the frame of reference of a serious poverty cycle in SA, resulting in escalating socio-economic deprivation, lack of education, joblessness (a large percentage of society being forced to rely on government grants for survival), and spiralling crime levels, as well as unemployment levels hovering between $40-46 \%$. These figures assume special significance if one takes into account that it has been pointed out repeatedly that 'cultural capital' (a person's perception of his/her environment) has to be considered in the planning of intervention programmes (Hernes, 2002). The school and community infrastructure and management have a major impact on the effectiveness of intervention programmes.

Peterson (1997: 11) states that teachers experience difficulty distinguishing between children's outward appearances and behaviour and their true potential, mostly because "they do not share personal information readily. Their life experiences may not have given them the vocabulary, intellectual enrichment, social experiences, or modelling of behavior ... They may, in fact, be sullen and withdrawn. Hostile, and sensitive to slights - trained thoroughly by adults who disappoint. They may initially be difficult to work with". This author stresses the need for a flexible, accommodating approach to identify the "toughest at-risk" students' deep-seated needs and strengths.

Begoray and Slovinsky (1997) engage with the issue of preparing teachers to identify and accommodate gifted, low income learners and express the view that such learners may be likened to pearls in shells - hard to discover, yet, the search is undeniably worthwhile. Taking into account that gifted students from all walks of life need role models, the authors mention Vygotsky's view that a more sophisticated partner could assist a student by working in the zone of proximal development, thus deducing that a teacher should very well be the facilitator.

\section{Problems in many SA schools}

The following problems exacerbate the inadequacies of the education of the gifted in 
SA (Arnott, Kubeka, Rice \& Hall, 1997; Howie; 2001):

- Poor socio-economic background of learners (poor incentive to study at home).

- Lack of appropriate learner support materials.

- A generally poor school environment (including inadequate facilities, overcrowded classrooms, lack of teacher support mechanisms and shortages of textbooks).

- On the whole, a poor quality of teachers and teaching (including poor subject knowledge and poor motivation).

- Lack of time in over-full curricula.

- A peer environment that is not supportive of those who wish to do well academically.

- Communication problems due to the fact that language of instruction is often not the same as the learners' mother tongue.

- Far too often the emphasis in education is still on the "how?" of education rather than on the context within which learning takes place. It seems as if attempts to resolve or do away with the present unsatisfactory situation could be successful only if the learning milieu of gifted learners is improved drastically.

A brief overview of the provision of education for the gifted in the United States of America (USA) is deemed necessary and will be followed by a review of the South African situation during the previous (pre-1994) dispensation.

\section{The situation in the USA}

The United States of America (USA) has a longer history of gifted education than many other countries, since the first school for the gifted was established in Worcester, Massachusetts in 1901: "because of its century-old head-start in gifted education, American practice has almost become an accepted benchmark, at least in the Western World” (Freeman 2002: 5). 
The education of the gifted child has received much attention and publicity in the USA over a number of decades. Many programmes for the gifted were implemented between 1867 - 1957 (Coetzer \& van Zyl, 1989: 129; Freeman, 2002: 6).

The Marland Report followed an intensive investigation into matters concerning gifted children and led to the establishment of a number of offices and centres for the gifted, including the Educational Resource Information Centre Clearinghouse on the Gifted and Talented (ERIC Clearinghouse) (Coetzer \& van Zyl, 1989: 136; Freeman, 2002: 10; Sherman, 1997: 5).

The last quarter of the $20^{\text {th }}$ century was marked by an upsurge of interest in gifted education, e.g. between 1982 -1983 the Texas Education Agency increased funding for gifted education from two to eight million dollars (Freeman, 2002: 7); in 1995 the National Research Centre on the Talented and Gifted was established with funding as a result of the Jacob K. Javits Gifted and Talented Education Act.

Unfortunately interest in gifted education seems to have diminished lately, as the number of states mandating gifted education dropped from 50 in 1993 to 23 in 2002, consequently decreasing the number of gifted programmes and enrichment courses significantly (Freeman, 2002: 10).

\section{The situation in SA}

According to Lategan (1986) giftedness as a pedagogic issue was characterised by two phases during the apartheid era, namely the first, during which differentiation was implemented nationally and which is regarded as non-intentional provision for the gifted, and the second phase, during which the four education departments attempted to provide specifically for the gifted.

In 1965 the Institute of Manpower Research of the Bureau for Educational and Social Research embarked on a longitudinal research project which involved the 
monitoring and testing of 70000 white learners (Lategan, 1986: 311; Coetzer \& van Zyl, 1989: 148) and emphasised the importance of education for the gifted child.

The new system of differentiated education was implemented in accordance with Law 39 of 1967 and provided for gifted children by allowing them to follow curricula in specific subjects on the higher grade and also by offering computer science as a seventh (extra curricular) subject. In addition a number of "vacation schools" were instituted after 1980. Provision was also made for children gifted in certain areas, e.g. by the end of 1981 there were 140 extra curricular music centres attached to schools, three for ballet and seven for art (Coetzer \& van Zyl, 1989: 150).

Most attempts at special provision for the gifted child involved out-of-school projects at the above-mentioned centres. In addition, in Natal, afternoon activity periods were held at resource centres. An academic planner paid regular visits to schools to prepare and assist teachers. Schools were also visited by overseas authorities.

In the 1980s a number of extra curricular centres for the gifted were established in the erstwhile provinces of Transvaal, Natal, the Cape and the Orange Free State. Teachers' training colleges and universities were enlisted to offer courses to gifted learners at the extra curricular centres. In addition, provision was made by, among others, The Office for the Gifted and Talented in Port Elizabeth (1976), the Free State Society for Gifted Children (1980) (Bhorat, 1985: 36).

Teachers were encouraged to avoid giving "busy work" (Heller, Mönks \& Passow, 1993) in an attempt to cater to the needs of the gifted in the regular classroom. Although teachers were not specially trained to identify gifted children, many children were chosen by them to be taught at the extracurricular centres.

Two more recent initiatives are the Growth of Children's Potential Saturday morning township (Soweto and Daveyton) projects which are also parent-run and 
the TASC (Thinking Actively in a Social Context) project launched by the University of Natal, Curriculum Development Unit, Pietermaritzburg (Belle Wallace and Harvey Adams) to develop skills among poor black children (Freeman, 2002: 153).

Kokot (1998:58) describes the current status of gifted education in South Africa as "not encouraging" and "dismal" in light of the dismantling of the infrastructure built by the previous government, i.e. the closing down of centres for the gifted, and the co-opting to other departments of specialist teachers who used to oversee the education of the gifted in schools. The only programmes available in certain parts of the country, i.e. Natal and the Western Cape, are parent-driven.

\section{Outcomes-based education in SA}

A major feature of the post 1994 transformation process was the paradigm shift from an apartheid (exclusive) content-based education system to a democratic (inclusive) system. Efforts to transform the dual system consisting of a mainstream and a special education component into an inclusive one, have culminated in the emergence of a single, outcomes based system which was implemented for all grade one learners in 1998 (Carrim, 2002; Porteus 2003).

The critical outcomes are listed in the Revised National Curriculum Statement (RNCS) and envisage learners who will, among other things, be able to solve problems while thinking critically and creatively, demonstrate an understanding of the world as a set of related systems and manage themselves and their activities responsibly and effectively (National Department of Education, 2002: $1)$.

The research of Adams and Wallace (1993: 450), based on Vygotskian principles, and specifically related to the learning and problem solving process among children in small group settings, has also affirmed these lecturers' adoption of an interactive approach to student learning in the teacher education module "all school teachers should take responsibility for the needs of all children in the regular 
classroom". This has, to an extent come about through the implementation of Curriculum 2005 in South African public schools and is in keeping with Grovés (1990: 293) view that all learners in SA should be equipped by their teachers with "the necessary knowledge, skills, expertise and techniques in order to conduct independent research". Van der Horst (2000) states that "basic skills and values which lie at the heart of all educational endeavour in South Africa (therefore also for the gifted) are represented by the critical outcomes of Curriculum 2005".

It would seem as if the relatively new system could contribute greatly to the success of teachers in teaching both gifted and non-gifted learners, since it is largely based on the premise that learners should become adept at problem-solving. Practice, however, has shown that the training of teachers in the use of the new curriculum has not been very effective. This, coupled with the fact that many teachers and especially parents are hostile toward the new system, diminishes its effectiveness for all learners.

Kokot (1999: 270) complains that despite the publication of a number of official reports by the national education department and reports in the media, "the plight of the gifted learner is seldom mentioned ... it is generally hoped (in spite of doubts) that their needs will be met in the course of the outcomes-based approach".

\section{Inclusion}

Although the closure of the centres for the gifted in South Africa is widely regarded as detrimental to the nurturing of the gifted child in this country, the reality is that the government has implemented a policy of inclusion; hence the issue of fulfilling the educational needs of the gifted must be addressed within the given (inclusive) framework.

Since "inclusion" has different connotations, it is necessary to try to determine the meaning globally as well as in the South African context. Kearney (1996: 1) describes "full inclusion" as a term connected to the Civil Rights movement 
in the USA, that educators use to describe a philosophical approach which maintains that children with disabilities, even though these may be severe, be placed in the regular classroom for most or all of the school day.

According to Carrim, inclusion and exclusion are theoretically and empirically conjoined. Inclusion is regarded as a "means to an end - the creation and the maintenance of an inclusive society ...It is ultimately about the transformation of society and its formal institutional arrangements, such as education" (2002: 3). The concept of inclusion is often used in the context of "special education" but is currently used in a wider sense than to refer merely to including learners with disabilities in the regular classroom.

Despite the ostensibly clear-cut definitions of inclusion in the Constitution (1996), "it means different things at different educational moments and contexts" (Carrim, 2002: 11), for example, the "barriers to learning" approach described in the White Paper on Special Educational Needs, expands the notion of learning barriers to include people who may not be disabled, but who need special educational attention, e.g. HIV-positive people. The approach therefore applies inclusion in broad terms and attempts to mainstream the provision of education for all learners, including the disabled, thus reconfiguring the "exclusionary effects caused by apartheid" (Carrim, 2002: 11).

Although Carrim (2002) does not specifically mention the gifted, his statements imply that they could also be classified as learners with special educational needs, in the same way as those with disabilities, rape victims, etc. As Naicker (2002: 9-10) states: "special education theory is located within a functionalist paradigm and is concerned with learners who experience learning breakdown, as well as those who have gifted behaviours ... either enrichment or acceleration could be used to ensure that the gifted learner is not neglected". 
Cohen (in Sherman, 1997) favours inclusion, as she believes that the basic principles used to educate gifted children could be used as effectively to educate all children and that a pull-out programme for gifted children is insufficient "... because gifted children are gifted all the time, and their instruction in basic subjects must be modified to meet their learning needs" (1997: 10).

Kearney (1996: 2) also stresses the fact that gifted students have very few opportunities to interact with their intellectual peers in an inclusive system, which largely ignores the social and academic advantages of homogeneous grouping.

\section{Focus on the training of teachers of the gifted}

\section{Introduction}

Despite the disadvantages related to an inclusive system, such as that currently in use in South Africa, the need is therefore to consider ways in which the system can be utilised optimally. The major aspect on which one should focus is general teacher training which divides into pre-service and in-service training. The same issue has formed the focus of numerous studied in developed (First World) countries during the past decade.

Sherman (1997: 14) says that according to state-level gifted education directors in the USA "training for general-education teachers in how to serve gifted students is the field's biggest need nationwide". Furthermore, research does not bear out the common assumption "... that bright or brilliant students will shine without any special help ... most gifted students [work] at least four grades below that at which they could be working" (2002: 15). Carpenter agrees, the "lack of teacher training and prejudice could mean a gifted child is overlooked" (2001: 4).

Kokot's (1998: 35) view that the clarion call of gifted learners around the world is "school is boring" is supported by Sisk (2002), who mentions during an interview, that a consequence of the constant revision of work already mastered by 
gifted children is that they "learn" to underachieve. Sisk adds that gifted students are at the highest risk of not receiving the appropriate type of education in a regular classroom in an inclusive system (Seevers \& Shaughnessy, 2003: 18). Clearly, specialist training is essential before teachers should be allowed to teach gifted learners.

As early as 1984, at the Ingenium 2000 international conference on education for the gifted which was held in South Africa, Johan Garbers of the HSRC pleaded for the mainstreaming of education for the gifted child and for appropriate pre- and in-service teacher training to enable teachers to identify gifted children and to sensitise them to the needs of such children. He emphasised the fact that teachers should be able to apply a variety of teaching strategies.

\section{Lack of training}

According to Kokot (1999: 270) local teachers have indicated that they received either very little training on gifted children or none at all. Furthermore, in addition to the certificate course in Gifted Education at UNISA, "mention of gifted children is made in all undergraduate courses", while postgraduate courses are not well supported possibly because of the lack of interest on the part of schools and education departments.

Yet, owing to the fact that teacher colleges and universities exert a direct influence on the education of gifted children by training (or not training) future teachers, they should be the major focus of advocates for improving gifted education. One of the problems, however, with teachers' colleges and universities, is the lack of training of faculty in regard to teaching the gifted. Lyon, Vaasen and Toomey (1989: 169) assert that because many professors of education have not themselves taught in classroom settings, "their content expertise and applied knowledge of pedagogic principles" are limited (also see Davison, 1996: 44). Lyon et al. (1989: 169) feel the solution to this dilemma would be to turn the scholarship that is the major focus of teacher educators toward the integration of theory and practice and to prepare 
teachers within school settings "under the conditions that teachers will ultimately be faced with" in schools. This would probably be a popular method among trainee teachers who have been found by Lyon, et al. to believe that they "develop expertise primarily through their own teaching experiences" (1989: 168). In this connection Ribich, Barone \& Agostino, 2001: 311) agree that pre-service teacher candidates should be allowed to process and critically examine the dynamics they observe and to apply this information when they teach different populations of students, but warn against unsupervised field experiences for pre-service teachers as these "may reinforce latent biases and stereotypes. Field experiences need to be carefully selected and supervised".

\section{Teaching gifted learners in regular classrooms}

According to Bonner (2000) "Teachers must be properly trained if they are to serve as conduits to gifted and talented programmes. Proper training should include not only specific gifted and talented identification measures, but information on multiculturalism and diverse learning styles as well" (648).

An effective way of addressing the challenges would be to win over one or more teachers from each school in SA and to raise their morale, since they constitute "the one group that is most critical to these profound reforms" Ainscow, 2000:101).

Renzulli (in Knobel \& Shaughnessy, 2002: 121) admits that teachers in the regular classroom can achieve success in regard to educating gifted learners effectively, but only up to a point and with difficulty. He has always been fascinated by the fact "that the policy makers who argue for inclusion, little or no special services, and even criticize gifted education initiatives - are often persons who send their own children to private schools" and regards differentiation as "a smokescreen behind which bright kids get a few extra assignments or more work based on traditional (didactic) models of learning". 
The majority of authors on gifted education agree in principle that adequate provision can be made for the gifted child in the regular classroom (Ainscow, 2000; Blumen-Pardo, 2002; Maker 1986) while a number feel that gifted learners should be taught separately for at least part of the time (Sisk in Seevers \& Shaughnessy, 2003; Torrance in US News \& World Report, 1980).

\section{Gifted education as a form of special education}

The idiosyncratic needs of the gifted should be attended to as special needs. In this regard, Torrance feels strongly that the gifted should be offered a fair chance through special schooling and that the same effort needs to be made for them as for others (US News \& World Report, 1980). Sherman (1997: 15) expresses a similar opinion when he states that the assumption that bright or brilliant students will thrive without special assistance has been disproved in research, as “... most gifted students are working at least four grades below that at which they could be working".

\section{Compulsory courses for future teachers}

Grové (1990: 297) is concerned about the perception of many teachers that their schools do not have gifted learners and the general assumption that the gifted child must be catered for "elsewhere", i.e. not in the regular classroom. She is in favour of compulsory courses in gifted education for all undergraduate teachers in training and for all who wish to follow a postgraduate course in education.

\section{Curricula in gifted education}

Clearly, learning programmes in SA schools and tertiary training institutions need to be adapted and revisited so as to provide clear guidelines to trainee teachers. Sadly, this matter has been neglected to a significant extent. Dealing with the gifted is, after all, a crucial and highly specialised activity which requires extensive training and demands careful planning and execution. 
Passow and Schiff (1989) propose the following six broad areas in which intervention with the gifted could take place:

- Involving the gifted in strategies to facilitate peace and disarmament and developing social conscience and a sense of social responsibility;

- Prompting them to consider what the future holds (a view supported by Necka, 1989);

- Encouraging them to question the morality and ethicality of subject areas, and not to shy away from asking conscience questions about the contents of subject areas;

- Motivating them to engage actively in studying to solve real-life challenges;

- Guiding them to read about, scan and engage in critical discussions about news media intelligently and on a regular basis;

- Facilitating networking opportunities for the gifted, both nationally and internationally.

Gifted education teacher training curricula will also need to include a module on domain-specific intelligences. Gardner's (1999) definition of multiple intelligences (and his distinction between nine intelligences) is widely regarded as a traffic light in the field of giftedness and should be included in such a curriculum. In addition, spiritual intelligence, a tenth intelligence (Sisk, 2002) and the concept of wisdom (Sternberg, 2001) should be included in such a curriculum as well.

Sternberg (2001: 11-12) argues that wisdom can be developed in a number of ways, including the following seven:

- Students need to be provided with problems that require wise thinking, e.g. problems which require negotiations between parties, giving advice to others, or dealing with ethical/ moral dilemmas.

- Students need to be helped to think in terms of the common good.

- In solving problems, students need to learn how to balance their own interests with those of other people and institutions.

- Students must be provided with and analyse examples of wise thinking from 
the past.

- Facilitators should role model wisdom for their students.

- Facilitators must help their students think dialectically, keeping in mind that most major world problems do not have right or wrong answers, but rather more accurate and less accurate ones. Furthermore, students need to understand that the concept of right and wrong is relative, and can vary according to time, place and context. .

- Facilitators need to prove to their students that they value wisdom by rewarding them for wise information processing and problem solving.

Once these steps have been followed in the classroom, both facilitators and students need to apply (carry) what they have learned, outside the classroom.

Furthermore, teachers should be introduced to the notion of an increased emphasis on emotional intelligence (EI) and less emphasis on IQ. A number of years before the phrase "emotional intelligence" (EI) was officially coined, Hoffman, Wasson and Christianson (in Newell, 1989: 98) provided the following checklist as a yardstick for identifying gifted underachievers: A typical underachiever has a high IQ, but shows a discrepancy between expected and actual performance, is inconsistent in accomplishing goals, displays impaired levels of self-confidence, reveals feelings of inferiority, blames others for his or her own troubles and shows evidence of withdrawal. This checklist already offers ample proof that a measured high IQ alone does not "guarantee" satisfactory achievement and that other factors have to be considered as well, when attempting to explain the variance in human achievement.

In 1990, Salovey and Mayer (1990) noted that intelligence should be redefined in order to include a person's capacity to monitor his or her own and others' emotions, to discriminate among these emotions and to use this information to guide his or her thinking and actions. This shift has given rise to the definition of the concept of "emotional intelligence". 
Lastly, Van Tassel and Wills (in Begoray, \& Slovinsky, 1997) express the view that nonverbal approaches need to be introduced into classrooms, since they facilitate the identification and involvement of gifted students more sufficiently. As Ford and Harmon (2001) so aptly state, facilitators should realise that nonverbal assessment instruments identify intelligence in a nonverbal way. Since many gifted students may not possess high verbal skills, or may be compelled to study in a second or even third language (often the case in SA), it goes without saying that nonverbal assessment instruments afford candidates an opportunity to be assessed in a fair and less biased way than verbal instruments.

Van Tassel and Wills (in Begoray, \& Slovinsky, 1997) highlight the fact that teachers (especially those from less disadvantaged environments), fail to identify giftedness in students who are 'different' from others, e.g. those who have dissimilar attitudes, speech patterns or dress. These authors argue that formal assessments have to be viewed with caution and that individual assessments are more likely to identify giftedness accurately. Zorman (1991) for instance, refers to the potential value of systematic observations in identifying giftedness.

\section{In-service training}

Bhorat (1985: 21-22) says that the preparation of teachers in regard to gifted children during the previous dispensation in SA occurred mainly by means of in-service programmes at teachers' centres throughout the provinces. Courses for teacher training were "virtually non-existent, with the exception of courses provided by the University of Port Elizabeth" where gifted education was a basic module for final year education students.

A number of in-service teachers registered at the erstwhile College of Education for Further Training (CEFT) for the two-year diploma course in Gifted Education, which was implemented during 1985. 
It would seem logical to advocate in-service training for general education teachers to empower them to provide effectively for the gifted learner, yet studies have shown that student who are not trained prior to being appointed as teachers, will probably not receive in-service training (Davison, 1996). According to Freeman (2002: 84) in-service training is the only training offered to teachers of the gifted in Belgium, but only on an irregular basis.

Clinkenbeard and Kolloff (2001: 218) advocate approaches "that will provide awareness, basic information, strategies and resources for novice teachers" who will most likely all encounter gifted students. In support of this view, Davison (1996: 42) argues for all teachers to be taught how to meet the needs of gifted students since such students "spend most of their classtime in the regular classroom".

\section{Tutoring, mentoring, networking and online training}

Renzulli's opinion on teacher training is that trainees should be placed with master teachers under whose tutelage they may thrive (Knobel \& Shaugnessy, 2002). This would be a feasible solution if there were enough master teachers with whom to place large numbers of students, unfortunately the chequered past of gifted education world-wide has resulted in relatively few master teachers of gifted children remaining to mentor trainees.

Although many beginner teachers feel generally well-prepared for the demands of teaching diverse types of learners some feel that their study programmes and field experiences do not equip them to meet the needs of a diversity of learners (Lyon, et al., 1989; Miller, Strosnider \& Dooley, 2002). This underwrites the view of Ribich et al., viz. that stricter supervision is needed during the practicum periods (2001).

The reason a large number of novice teachers feel under-prepared for teaching, especially in light of the growing numbers of students from a variety of backgrounds is that some undergraduate majors take only a single course in special 
education - sometimes constituting one chapter or a week of lectures (Clinkenbeard \& Kolloff, 2001).

Herbert (1997) who explored the complexities of mentoring a gifted student from a disadvantaged background argues that personalised school environments are desperately needed to help disadvantaged gifted students develop their potential. Other salient aspects which should be considered in regard to assisting at-risk students include the support of caring adults and nurturing these students' specific strengths. Most importantly, Herbert emphasises the need for teachers to adopt flexible strategies in their attempts to support gifted students. Hayes, Ryan and Zseller (1994) argue convincingly that teaching which provides love and caring (emotional support) increases the opportunity for gifted students to develop psychologically, emotionally and socially.

Teachers need to be taught to establish networks with a wide variety of others. Action research in classrooms should be self-evaluative in the sense that both theoretical and practical aspects should be critically interpreted continuously. Classroom strategies to facilitate this are essential (including not avoiding questions, allowing open questions and stimulating discussions about future developments). Learning programmes in SA schools and tertiary training institutions need to be adapted and revisited so as to provide clear guidelines to trainee teachers for dealing with the gifted in classrooms, including a renewed emphasis on the rights of the gifted, embedded within the broader framework of children's rights in general.

Although Sisk would prefer teachers to receive training at tertiary institutions where they can participate in intensive interactive sessions, she seems not to disapprove entirely of online courses: "I am not convinced that on-line can provide the same quality of teacher-training ... On-line is fine for knowledge and 'head stuff', but a great deal of learning is 'heart stuff'" (Seevers \& Shaughnessy, 2003: 23). A further alternative to consider would be online courses for pre-service as well as inservice teachers (Siegle, 2002), especially for people who live far from tertiary 
institutions or have financial constraints. In SA, though, online training is not yet a realistic option, especially since the majority of schools in the country do not yet have access to the basic commodity of electricity.

\section{Spotlight on the role of teachers of the gifted}

\section{Teacher qualities}

Numerous researchers have compiled lists of traits that would characterise good teachers of the gifted. Rizza and Gentry (2001), for instance, interviewed six leaders in the field of gifted education, i.e. Gallagher, Kaplan, Reis, Tomlinson, Renzulli and Van Tassel-Baska who listed the following requirements for a teacher of gifted children: a passion for teaching; the desire to become a lifelong learner - "if we are to instill in our students a disposition for lifelong learning, we ourselves must model such behavior" (2001: 174, 177); "to really understand the myriad characteristics of giftedness and myriad ways to challenge those" (2001: 177). However, Ball (1989) indicates that the role of the teacher-facilitator is not well-defined and that teachers of the gifted are required to assume the role of manager, rather than see themselves as "the ultimate source of authority in the classroom".

According to Baldwin (1993: 624) all the attributes listed by other authors can be classified according to the triad of categories proposed by Maker in 1982, viz. philosophical, professional and personal. A South African, Van der Westhuizen, is said to have added "attitude" to a comprehensive list of preferred character traits teachers of the gifted should display (Baldwin, 1993: 627).

In addition to a list of ten characteristics ranging from "likes gifted children" to "possesses and models joy in learning", Baldwin mentions that "high energy levels", "self-efficacy" and "creativity" have been listed regularly, while the most successful teachers of the gifted have been described as "facilitator(s) of learning" (1993: 624-625). Both Baldwin (1993: 624) and Smith regard the teacher as the vital factor, s/he has to have an affinity for the gifted children s/he teaches: “... love is vital 
to acceptance" and "the teacher needs to be a vivid person. We learn best ... not by instruction but by provocation" (Smith, 1984: 143).

\section{Attitudes of teachers of the gifted}

Ribich, et al. (2001:311) cite the Rosenthal studies that suggest that the learning climate created by teachers is a stronger determinant for successful learning than the actual instruction. This view underwrites John Holt's view that teachers (of the gifted) need "certain qualities of mind and heart" (in Eriksson, 1984: 170).

In many countries people regard special programmes for gifted learners as elitist. Kokot (1999: 269) alleges that in South Africa politicians believe that identifying minority (gifted) groups is counter to a democratic ideology - hence the move toward "inclusive, accessible and redressed education which requires ... redistribution of resources ... to eradicate previous injustices".

Gross concurs in principle, when she mentions that special programmes are viewed as "elitist, undemocratic, unnecessary, of low priority, or a drain on already limited funding" (2002: 26). Sherman (1997: 4) describes the elitism issue as the “equity versus excellence" problem where "democracy (which embraces equality) butts heads with intellectualism (which suggests elitism)", adding that nations are shaped by the notion that "all men are created equal" and that it is difficult to attend to equity and excellence issues simultaneously.

In Africa, especially in countries where the objective of education is primary education for all, it is difficult to justify separate programmes for gifted children particularly since gifted education is in many African countries associated with colonialism (Freeman, 2002: 152). Freeman's (2002: 1) solution is to include "potential" in definitions of giftedness so as to cut through the "elitist barrier". In this regard, Torrance (US News \& World Report, 1980: 4) asserts that all students should be given a fair chance - thus implying that the gifted receive special education - since all societies will always depend on a gifted, creative minority for 
their images of the future and he is "willing to accept some charges of elitism to accomplish that".

Wallace and Radloff (1992:117) state that "most importantly, teachers' attitudes must be changed if the development of human potential is to be both equal and equitable. The fact that it has been difficult to bring about a mind shift in regard to the education of learners in the regular classroom in South Africa, despite the official implementation of the new, government-instituted system, does not augur well for changing teacher attitudes in regard to gifted learners. Wallace and Radloff point out the necessity of funding to provide basic education for all children in the country, but highlight the necessity for a change in teacher attitudes if "the development of human potential is to be both equal and equitable" (1992: 117).

Ribich et al. (2001:311) support the view that teacher attitudes are paramount in creating an appropriate learning environment for all learners. Their research shows that teachers are less inclined to be supportive of students who are perceived to be underachievers "or not worthy of the label gifted" (2001: 311). One of the major problems cited by these researchers in this regard is that exposure to underachieving gifted students could give rise to hostile and negative stereotypes which would "shape teacher attitudes and expectations regarding these students - attitudes and expectations that become barriers to the process of learning and belie the egalitarian ideals that form the philosophical foundations of the nation's schools" (2001: 312).

Even if teachers in training do not possess the qualities mentioned by Holt naturally, they can, according to Gross (2002: 26), be trained and exposed to research findings that contradict many of the misconceptions regarding gifted education.

\section{Teaching teachers to identify the gifted}

At the very least, teachers should be trained to identify giftedness. Criteria for identifying the gifted could include a combination of the following:

- Showing a potent dislike for structure and routine; 
- Failing to cooperate;

- Practising (uncommon) hobbies;

- Displaying natural leadership;

- Being uncommonly sensitive;

- Being flexible and able to look at things in novel or innovative ways;

- Willing to persist, to remain focused on a certain assignment, long after others have given up;

- Hiding behind a veil of mediocrity to disguise their giftedness (for fear of being rejected by the peer group);

- Becoming bored easily, not being prepared to mediate rote learning and 'traditional' teaching;

- Being independent with a keen desire to solve their own problems; and

- Identifying/sensing insensitivity or inconsistent behaviour immediately (Thompson \& Rudolph, 1992).

\section{Multicultural education}

Ford and Harmon (2001) argue that it is essential to educate teachers regarding multicultural education. These authors propose that teachers be trained with regard to the following aspects:

- Engaging in critical self-examination to explore their own attitudes and perceptions in respect of cultural diversity, and especially the possible impact of these aspects on learners' educational opportunities and achievements;

- Acquisition and use of accurate information concerning cultural diversity, and using this information to inform their own learning facilitation;

- Learning (how) to infuse their multicultural insights and perspectives into classroom practice; and

- Networking with a variety of groups, including parents, communities and organizations.

\section{Results of the quantitative part of the study}


Currently only two universities, i.e. the University of South Africa (UNISA) and the University of Pretoria appear to offer courses in gifted education. At UNISA students may do a year certificate course in Gifted Child Education (7027-0) and at the University of Pretoria a compulsory "Giftedness and talent development" component is offered as part of the Special Needs Education course (JSN 320). The course at the University of Pretoria is offered as an elective (JSN 120, JSN 210 and JSN 320) in the first three years of study in the Bachelor of Education (BEd) programme. In the final (fourth) year it is a compulsory module (JSN 451) for all foundation phase students.

Decisive leadership is of the essence and as many stakeholders as possible need to be actively involved in the process. These stakeholders include the state, the psychology and education fraternity, parents, and obviously, the gifted disadvantaged themselves. Research needs to be conducted regarding a number of aspects (spelled out in this article), including research regarding the status of the gifted in $21^{\text {st }}$ century classrooms where (the recently adapted version of) Curriculum 2005 holds sway. A national indaba should involve significant stakeholders and rolling five year-plans need to be adopted, after which the results of intervention strategies need to be gauged, while plans should be adapted and revised.

Battling the poverty cycle, escalating socio-economic deprivation, lack of education, joblessness and spiralling crime levels, requires vision and wisdom ... from all concerned. This could be brought about in the near future as teacher trainees at SA universities are being trained to teach according to the RNCS and "prepared to deal with the schools as they exist", they must, however, "be taught how to use the information about the diverse groups that constitute our schools so that they can adapt instruction to fit the idiosyncratic needs of all learners"' (Ribich et al., 2001). 


\section{Conclusion}

It seems clear that bold steps need to be taken to train teachers effectively so that they will be able to fulfil the needs of all the learners in their diverse classrooms.

All teacher training institutions should offer compulsory programmes on gifted education and subject content areas for all teacher trainees, and teachers already employed should be afforded the opportunity of attending workshops and seminars (Feldhusen, 1985: 89). Another possibility would be for teachers to attend courses on gifted education with the trainee teachers at the institutions closest to their schools if these were offered outside school hours. This would require no extra personnel, planning, or financial outlay by tertiary institutions. 


\section{References}

Ainscow, M. (2000). Reaching out to learners: Some opportunities and challenges. In H. Daniels (ed.) Special education re-formed: Beyond rhetoric? London: Falmer Press.

Arnott, A., Kubeka, Z., Rice, M. and Hall, G. (1997). Mathematics and Science teachers: demand, utilisation, supply, and training in South Africa. Craighall: Edusource.

Adams, H.B. \& Wallace, B. (1993). World perspectives on the gifted disadvantaged. London: A B Academic.

Baldwin, A.Y. (1993). Teachers of the Gifted. In A. Heller, F.J. Mönks \& H. Passow (eds.) International handbook for research and development of giftedness. England: Pergamon Press.

Ball, M. M. (1989). A study of the facilitative role of the teacher in the implementation of gifted education in schools. Unpublished MEd dissertation, University of Port Elizabeth.

Begoray, D. \& Slovinsky, K. (1997). Pearls in shells. Roeper Review, 20(1):45-49. [Online serial]. URL http://search.epnet.com/direct.asp?an=9710254863anddb=aph. Accessed 03 May 2005.

Bhorat, F. (1985). Educational provisions for the gifted Indian child in the Republic of South Africa. Unpublished Med dissertation, UNISA.

Blumen-Pardo, S. (2002). Effects of a teacher training workshop on creativity, cognition, and school achievement in gifted and non-gifted second-grade students in Lima, Peru. High Ability Studies, 13, 1, 47-58.

Bonner, F.A. (2000). African American giftedness: Our nation's deferred dream. Journal of Black Studies, 30, 5, 643-663.

Carpenter, M. (2001). The IQ factor: Despite advances in defining gifted children, intelligence testing still plays a large role. Post-Gazette News. June 10.

Carrim, N. (2002). Inclusion in South African Education. Institute of Development Studies, Discussion Paper no. 2.

Clinkenbeard, P. R. \& Kolloff, P. B. (2001). Ten suggestions for including gifted education in preservice teacher education. The Teacher Educator, 36, 3, 214-218.

Coetzer, I.A. \& Van Zyl, A.E. 1989. Die historiese opvoedkunde: Enkele eietydse opvoedingsvraagstukke (The historical education: Some contemporary challenges in education.). Study guide. Pretoria: UNISA.

Constitution of the Republic of South Africa 1996 
Davison, J. (1996). Meeting state mandates for gifted and talented: Iowa teacher preparation programs. Roeper review, 19, 1, 41-43.

National Department of Education (2002) Revised National Curriculum Statement. Gazette no.: 23406. Vol. 443. May 2002 Pretoria: Government Printers

Eriksson, G. (1984). Reflections of giftedness: A guide for students, parents and teachers.

Pretoria: HAUM

Feldhusen, J.F. (1985). The teacher of gifted students. Gifted Education International, 3, 2, 87-93.

Ford, D.Y. and Harmon, D.A. (2001). Equity and excellence: Providing access to gifted education for culturally diverse students. Journal of Secondary Gifted Education, 12, 3, 141.

Freeman, J. (2002). Out-of-school education provision for the gifted and talented around the world. Report to the DfES.

Gardner, H. (1999). Intelligence reframed: multiple intelligences for the 21st century. New York: Basic Books.

Gross, M. (2002) Musings: Gifts to the gifted - training our teachers. Understanding Our Gifted 15, 1, 25-27 Fall.

Grové, H. (1990). 'n Didaktiese analise van onderrigleermodelle vir begaafde onderwys. (A didactical analysis of teaching-learning models for gifted education.) Unpublished Med mini-dissertation. Port Elizabeth: University of Port Elizabeth.

Hayes, C.B., Ryan, A. and Zseller, E.B. (1994). The middle school child's perceptions of caring teachers. American Journal of Education, 103, 1, 1

Heller, A. Monks F.J. \& Passow, H. (1993). International handbook for research and development of giftedness. London: Pergamon Press.

Herbert, T.P. (1997). Jamison's story: Talent nurtured in troubled times. Roeper Review, 19, 3, 142.

Hernes, G. (2002). UNESCO vs HIV/AIDS. The history and ten lessons. Perspectives in Education, 20, 2, 115.

Howie, S. (2001). Mathematics and science performance in Grade 8 in South Africa. 1998/1999.

Pretoria: Human Sciences Research Council.

Kearney, K. (1996). Highly gifted children in full inclusion classrooms. Highly Gifted Children, 12,4 .

Knobel, R. \& Shaughnessy, M. (2002). A reflective conversation with Joe Renzulli. Gifted Education International, 16, 2, 118-126.

Kokot, S.J. (1998). Fulfilling potential: Options for educating gifted learners in South Africa. Research report, UNISA, April 1998.

Kokot, S.J. (1999). Discovery learning: founding a school for gifted children. Gifted Education 
International, 13, 3, 269-82.

Lategan, M.M. (1986). Onderwys vir die begaafde kind - ‘n histories-pedagogiese deurskouing. (Education for the gifted child: - a historical overview.) Unpublished thesis. Pretoria: UNISA

Lyon, G.R., Vaassen, M. \& Toomey, F. (1989). Teachers' perceptions of their undergraduate and graduate preparation. Teacher Education And Special Education, 12, 4, 164-169.

Maker, J.C. (1986). Critical issues in gifted education: Defensible programs for the gifted. USA: Aspen.

Miller, M., Strosnider, R. \& Dooley, E. (2002). States' diversity requirements for teachers. Teacher Education and Special Education, 25,1, 32-40.

Naicker, S. M. (2002). From apartheid education to inclusive education: The challenges of transformation. International education summit for a democratic society.

Necka, E. (1989). Stimulating curiosity. Gifted Education International, 6, 25.

Newell, M. (1989). Adapting the triads model to serve gifted underachievers. Gifted Education International, 6, 98.

Passow, A.H. and Schiff, J.H. (1989). Educating gifted persons who are caring and concerned. Gifted Education International, 6, 5.

Peterson, J.S. (1997). Bright, tough, and resilient - and not in a gifted program. Journal of Secondary Gifted Education, 97, 8, 121.

Porteus, (2003). Constructing an analytic framework for inclusion / exclusion for the decolonising context. Perspectives in Education, 21, 3, 13-23

Ribich, F., Barone, W. \& Agostino, R. (2001). Semantically different: preservice teachers' reactions to the gifted student concept. The Journal of Educational Research, 91, 5, 308312.

Rizza, M. \& Gentry, M. (2001). A legacy of promise: Reflections, suggestions and directions from contemporary leaders in the field of gifted education. The Teacher Educator, 36, 3, 167-84.

Salovey, P. and Mayer, J.D. (1990). Emotional intelligence. Imagination, Cognition and Personality, 9, 185.

Seevers, R. \& Shaughnessy, M. (2003). Reflective conversation with Dorothy Sisk. Gifted Education International, 17, 1, 16-41.

Sherman, L. (1997). Curiouser and curiouser. Northwest Education. Fall. http://www.nwrel.org/nwedu/fall/97/article2.html

Siegle, D. (2002). Learning online: A new educational opportunity for teachers and parents. 
Gifted Child Today Magazine, 25, 4.

Sisk, D. (2002). Spiritual intelligence: The tenth intelligence that integrates all other intelligences. Gifted Education International, 16, 3, 208.

Smith, E. (1984). Giftedness on demand in every classroom. Gifted Education International, 2, 2, 142-144.

Sternberg, R.J. (2001). Wisdom and education. Perspectives in Education, 19, 4, 1.

Thompson, C.L. and Rudolph, L.B. (1992). Counselling children. Pacific Grove, California: Brooks/Cole Publishing Company.

US News and World Report, (1980). For many, being gifted brings lifelong struggle. Interview with E. Paul Torrance.

Van der Horst, H. (2000). A Problem-solving strategy for gifted learners in South Africa. Gifted Education International, 15, 1, 103-110.

Wallace, B. \& Radloff, J. (1992). Looking at giftedness in a developing country. Gifted Education International, 8, 2, 116-117.

Zorman, R. (1991). Identification and nurturance of young disadvantaged gifted children. In Milgram, R.M. (ed). Counselling gifted and talented children: a guide for teachers, counselors and parents. Norwood: Ablex 161.

Prof. Maree is a triple doctorate, author or co-author of more than 37 books, and 80 articles, renowned psychologist, internationally known scholar. Editor of the journal Perspectives in Education, C-rated researcher with the National Research Foundation, he was honoured with exceptional achiever status by the University of Pretoria (2004-2006). He received the annual Research Medal for the Promotion of Education in 2002 by the Educational Association of South Africa, and the Association's medal for exceptional research in 2006.

Dr Carol van der Westhuizen is a senior lecturer and teaching practice and internship organizer for the School of Teacher Training in the Faculty of Education at the University of Pretoria. She teaches research methodologyl and her research interests include teaching practice-related issues, gifted education, educational change, mergers and the teaching of literature.

Education Faculty, University of Pretoria, 0001, Pretoria, South Africa Email: jgmaree@icon.co.za 
